\title{
Alkylphenol ethoxylates and bisphenol $A$ in surface water within a heavily urbanized area, such as Paris
}

\author{
M. Cladière, J. Gasperi, S. Gilbert, C. Lorgeoux \& B. Tassin \\ Université Paris-Est, LEESU, UMR-MA102 - AgroParisTech, France
}

\begin{abstract}
This work focused on alkylphenol ethoxylates (APEOs) and bisphenol A (BPA) in surface water at the scale of the upper part of the Seine basin. Although this basin is vulnerable, since it undergoes a combination of strong human pressures (Paris conurbation) with very limited dilution via the Seine River, no comprehensive data was available for these compounds. In this context, the evolution of the pollutant concentrations and loads was assessed during two sampling campaigns (April and July 2009) along a $300 \mathrm{~km}$-transect. Hence, 18 stations (10 sites on the Seine River, four tributaries and four wastewater treatment plants - WWTPs) were considered. Additional campaigns were also conducted over 2009 on four sites on the Seine River. The BPA concentrations

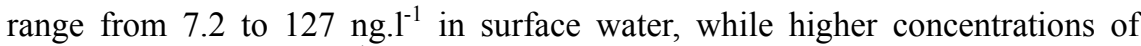
APEOs $\left(324 \pm 153\right.$ ng. $\left.^{-1}\right)$ were observed. Based on our first results, no spatial variability of concentrations between up- and downstream sites, or any seasonal variability, were highlighted. During the longitudinal campaigns, an increase of the pollutant loads between up- and downstream sites was clearly noticed. Contrary to BPA, for which a limited seasonal variation of loads was observed at the basin outlet $\left(1,400\right.$ and $\left.1,500 \mathrm{~g} . \mathrm{d}^{-1}\right)$, the APEO loads significantly vary $\left(10,000\right.$ and 5,500 g.d $\left.\mathrm{d}^{-1}\right)$. Mass balances between the inputs (tributaries + WWTPs) and the exported loads reveal that the BPA inputs are lower than the exported loads, suggesting that other inputs have to be considered along the transect studied. For APEOs, the inputs appear higher than the exported loads, underscoring the in-stream removal of APEOs. Globally, the results reveal that the removal of APEOs and the number of ethoxylate units are correlated - the longer the ethoxylate chain, the higher the removal.

Keywords: alkylphenol ethoxylates, bisphenol A, endocrine-disrupting compounds, mass load, nonylphenol, octylphenol, surface water.
\end{abstract}




\section{Introduction}

Among the endocrine-disrupting compounds commonly pointed out in the literature, alkylphenol ethoxylates (APEOs) and bisphenol A (2,2-bis(4hydroxyphenyl)propane, BPA) deserve special attention, not only because of their disrupting properties but also for their widespread distribution in the environment $[1,2]$.

APEOs, mainly composed of nonylphenol ethoxylates (NPEOs, 80\%) and octylphenol ethoxylates (OPEOs, 20\%), are widely used for industrial, domestic and commercial applications, such as lubricating, oil additives, detergents and antistatic agents. Similarly, BPA is mainly used as a monomer in the synthesis of epoxy resins and polycarbonate plastics [3,4]. Due to these applications, the worldwide annual production is approximately 500,000 tons for APEOs (in 2002, according to Ying et al. [5]) and 450,000 tons for BPA (in 2007, according to Vandenberg et al. [4]).

The occurrence of APEOs and BPA in the environment is closely correlated with anthropogenic activities. Many studies suggested that these chemicals preferentially enter into environment through the effluents of wastewater treatment plants (WWTPs) $[5,6]$.

Contrary to BPA, for which the estrogenic activity was clearly observed $[1,2]$, APEOs are of concern because their degradation products are found to be more toxic than their precursors [7, 8]. Biotransformation pathways of alkylphenol ethoxylates are well documented $[9,10]$. This biodegradation can occur through the oxidative hydrolytic (aerobic) or non-oxidative hydrolytic pathways. This last pathway leads to the reduction of the number of ethoxy units generating APEOs with shorter ethoxylate chains, such as alkylphenol diethoxylate $\left(\mathrm{NP}_{2} \mathrm{EO}\right.$ and $\left.\mathrm{OP}_{2} \mathrm{EO}\right)$ and alkylphenol monoethoxylate $\left(\mathrm{NP}_{1} \mathrm{EO}\right.$ and $\left.\mathrm{OP}_{1} \mathrm{EO}\right)$. Ultimately, the last products of biodegradation are 4-nonylphenol (NP) and 4-tert-octylphenol (OP), which are identified as endocrine-disrupting compounds $[1,11]$.

The Seine Basin, located in north-western France and responsible for draining approximately $32,000 \mathrm{~km}^{2}$ from its headwaters to Paris, can be considered as representative of river basins exposed to the impacts of intense human activity (Meybeck et al. [12]). This basin accommodates a combination of strong human pressures with very limited dilution via the Seine River, due to its low flow rate. However, no comprehensive data on the occurrence of APEOs and BPA is presently available for the upper part of the Seine basin. As regards the environmental issue of these chemicals, an accurate knowledge at the scale of the Seine Basin, and more especially within the Paris Region, corresponding to the most heavily urbanised area (with a density of roughly 3,540 inhabitants. $\mathrm{km}^{-2}$ ), has definitely proved necessary.

As a consequence, this study was launched to provide the first relevant information on the occurrence and significance of the concentrations of APEOs and BPA in surface water at the scale of the upper part of the Seine basin. In this paper, we particularly examine (i) the concentrations in surface water and 
WWTP effluents, (ii) the spatio-temporal variability of loads and finally (iii) the environmental behaviour and fate of APEOs and BPA along the Seine River.

\section{Materials and methods}

\subsection{Sampling sites}

Two sampling campaigns, corresponding to the median-water period (14/04/09, median flow at $\left.154 \mathrm{~m}^{3} \cdot \mathrm{s}^{-1}\right)$ and the low-water period $(07 / 07 / 09$, median flow at $\left.83 \mathrm{~m}^{3} \cdot \mathrm{s}^{-1}\right)$, were carried out along a $300-\mathrm{km}$ transect of the Seine River. For each campaign 14 sites, including 10 stations on the Seine River $\left(\mathrm{S}_{1-10}\right)$ and four main tributaries $\left(\mathrm{T}_{1-4}\right)$, were considered (Figure 1). In parallel, the effluents of the four major WWTPs along this section were investigated $\left(\mathrm{WWTP}_{1-4}\right)$. The main characteristics of these WWTPs (type of treatment, population equivalent, capacity, etc.) are reported in Figure 1. Two additional campaigns were also performed on $11 / 05 / 09$ and $28 / 09 / 09$ on four sites $\left(\mathrm{S}_{1}, \mathrm{~S}_{3}, \mathrm{~S}_{5}\right.$ and $\mathrm{S}_{8}$ stations).

\subsection{Analytical procedure}

For each site, a 2L-sample was manually collected and stored in glass amber bottles until analysis. After filtration on glass fibre filters (GF/D $2.7 \mu \mathrm{m}$ and $\mathrm{GF} / \mathrm{F} 0.7 \mu \mathrm{m}$ ), dissolved and particulate phases were individually analyzed.

\subsubsection{Dissolved phase}

Each water sample was spiked with internal standards (BPA-d6; n-OP-d17 and $\mathrm{NP}_{1}$ EO-d2) for extraction follow-up and stored overnight at $4{ }^{\circ} \mathrm{C}$ to reach an equilibrium state. Volumes of $250 \mathrm{ml}$ were extracted by solid phase extraction

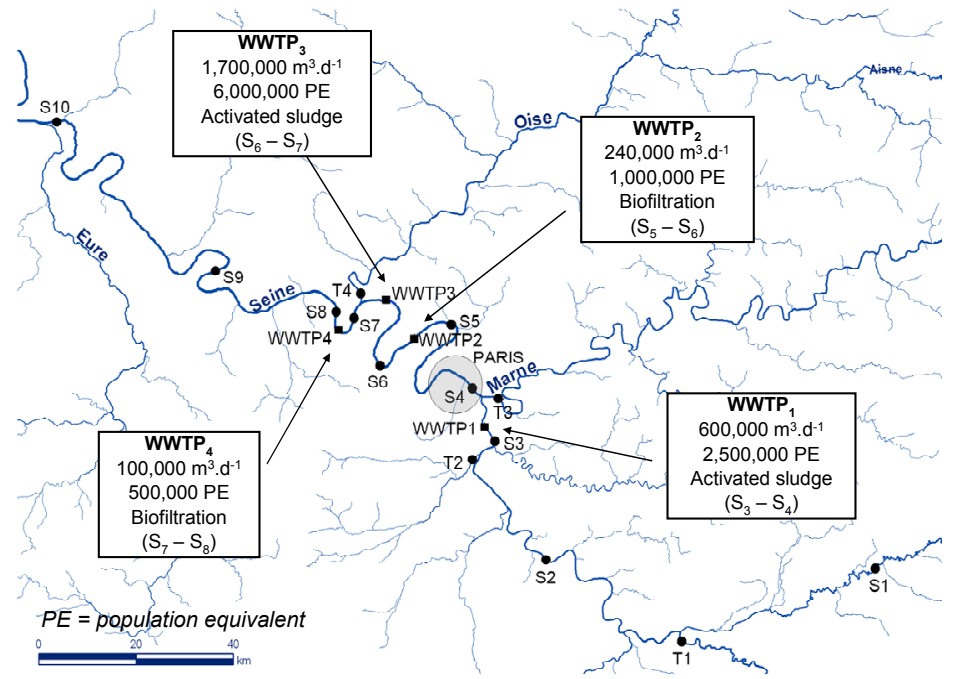

Figure 1: $\quad$ Sampling sites along the Seine River. 
(Autotrace SPE Workstation, Caliper LifeScience) using Oasis HLB (200 mg, 6 $\mathrm{ml}$ ) cartridges. After conditioning with $10 \mathrm{ml}$ of methanol and $10 \mathrm{ml}$ of ultrapure water, samples were extracted at neutral $\mathrm{pH}$. After drying under vacuum, elutions were performed with $12 \mathrm{ml}$ of a mixture methanol/dichloromethane/ethylacetate $(40: 40: 20, \mathrm{v} / \mathrm{v})$.

\subsubsection{Particulate phase}

After freeze-drying, the filters spiked with internal standards are extracted by microwave assisted extraction (MAE) with $20 \mathrm{ml}$ of dichloromethane/methanol (90:10, v/v) (Multiwave 3000, Anton Paar) during a 30 min-cycle. Extracts are then filtered and evaporated until dryness under nitrogen for subsequent clean up using silica gel cartridges. These cartridges are conditioned with $5 \mathrm{ml}$ of heptane before deposing the sample. Elution is done sequentially in three steps: $18 \mathrm{ml}$ of heptane/dichloromethane (98:2, v/v), $10 \mathrm{ml}$ of heptane/dichloromethane (80:20, $\mathrm{v} / \mathrm{v})$ and $10 \mathrm{ml}$ of heptane/dichloromethane/ ethylacetate (10:30:60, v/v). Only the last fraction is kept for BPA and APEOs analysis.

\subsection{LC-MS-MS conditions}

Before analysis, both extracts are spiked with internal standard for quantification (BPA-d16, n-NP and n-NP ${ }_{1} \mathrm{EO}$ ). The analysis is performed by liquid chromatography coupled to a tandem mass spectrometry, LC-MS-MS (AQUITY UPLC / TQD, Waters). APEOs and BPA are separated on an AQUITY UPLC / $\mathrm{BEH} \mathrm{C}_{18}$ column, heated at $40{ }^{\circ} \mathrm{C}$, with ultrapure water containing $4.5 \mathrm{mM}$ $\mathrm{NH}_{4} \mathrm{OH}$ (A) and methanol containing $4.5 \mathrm{mM} \mathrm{NH} \mathrm{mH}_{4} \mathrm{OH}$ (B) as mobile phase. Equilibration takes place with $50 \% \mathrm{~B}$ at $0.4 \mathrm{ml} . \mathrm{min}^{-1}$ and $10 \mu \mathrm{l}$ are injected. The mass spectrometer is equipped with an electrospray interface used in positive ionization mode $(\mathrm{ESI}+)$ for $\mathrm{NP}_{1-2} \mathrm{EO}$ and $\mathrm{OP}_{1-2} \mathrm{EO}$ and negative ionization mode (ESI-) for all other analytes. The compounds were detected in multiple reactions monitoring mode (MRM) with two mass transitions for each analyte. Cone voltage and collision energy were optimized for all analytes (Table 1).

Table 1: $\quad$ Optimized parameters for LC-MS-MS analysis.

\begin{tabular}{|c|c|c|c|c|c|c|c|c|}
\hline \multirow[b]{2}{*}{ 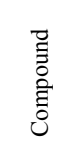 } & \multirow[b]{2}{*}{ 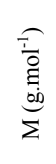 } & \multirow[b]{2}{*}{$\begin{array}{l}\stackrel{0}{0} \\
\sum_{0}^{0} \\
\tilde{D} \\
\text { II }\end{array}$} & \multirow{2}{*}{ 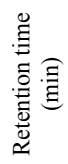 } & \multicolumn{2}{|c|}{ Quantification } & \multicolumn{2}{|c|}{ Qualification } & \multirow[b]{2}{*}{ 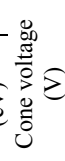 } \\
\hline & & & & 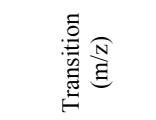 & 总 & :气 & 总㻤分 & \\
\hline BPA & 228 & ESI- & 1.82 & $226.9 \rightarrow 133.0$ & 25 & $226.9 \rightarrow 212.2$ & 25 & 30 \\
\hline $\mathrm{OP}$ & 206 & ESI- & 3.25 & $205.5 \rightarrow 134.2$ & 17 & $205.2 \rightarrow 133.2$ & 30 & 45 \\
\hline $\mathrm{OP}_{1} \mathrm{EO}$ & 250 & ESI+ & 3.34 & $268.2 \rightarrow 113.4$ & 10 & $268.2 \rightarrow 139.2$ & 12 & 20 \\
\hline $\mathrm{OP}_{2} \mathrm{EO}$ & 294 & ESI+ & 3.38 & $312.3 \rightarrow 183.3$ & 10 & $312.3 \rightarrow 121.2$ & 18 & 20 \\
\hline NP & 220 & ESI- & 3.52 & $219.2 \rightarrow 147.2$ & 26 & $219.2 \rightarrow 133.2$ & 26 & 40 \\
\hline $\mathrm{NP}_{1} \mathrm{EO}$ & 264 & ESI+ & 3.58 & $282.4 \rightarrow 127.3$ & 8 & $282.4 \rightarrow 85.4$ & 15 & 20 \\
\hline $\mathrm{NP}_{2} \mathrm{EO}$ & 308 & ESI+ & 3.61 & $326.4 \rightarrow 183.3$ & 10 & $326.4 \rightarrow 71.2$ & 20 & 40 \\
\hline
\end{tabular}




\subsection{Quantification and quality control}

The quantification was performed using internal calibration based on areas relative to the internal standards. Internal standard n-NP was used for the quantification of NP, OP and n-OP-d17. Similarly, BPA-d16 was used for BPA and BPA-d6 and n-NP ${ }_{1} \mathrm{EO}$ for $\mathrm{OP}_{1} \mathrm{EO}, \mathrm{OP}_{2} \mathrm{EO}, \mathrm{NP}_{1} \mathrm{EO}, \mathrm{NP}_{2} \mathrm{EO}$ and n-NP $\mathrm{NO}_{1}$ d2. For each compound, calibration curves were drawn and satisfactory determination coefficients were obtained $\left(\mathrm{r}^{2}>0.99\right)$. Experimental blanks for SPE and MAE extractions, as well as mobile phase blanks were processed. No quantifiable contamination was observed. During a sequence, two calibration controls (lower and higher concentrations) were injected every 10 samples. A deviation between the control and the calibration curve lower than $20 \%$ validates the quantification.

\section{Results and discussion}

\subsection{APEO and BPA in surface water and WWTP effluents}

\subsubsection{APEO and BPA concentrations}

Total concentrations (median \pm standard deviation, SD) measured for the Seine River, its tributaries and the WWTP effluents are shown in Figure 2.

As illustrated in Figure 2, BPA concentrations are quite similar in surface

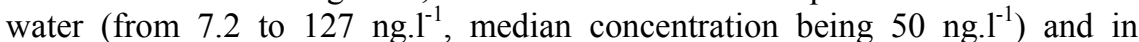

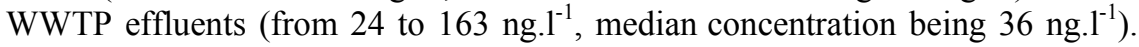
No significant difference was also observed between the Seine River and its tributaries. For APEOs, the distributions within surface water are featured by the predominance of $\mathrm{NP}$, followed by $\mathrm{NP}_{2} \mathrm{EO}$ and $\mathrm{NP}_{1} \mathrm{EO}$ while OPEOs exhibit far lower concentrations ( $<1 \mathrm{ng} . \mathrm{l}^{-1}$ for $\mathrm{OP}_{1} \mathrm{EO}$ to $20 \mathrm{ng} . \mathrm{l}^{-1}$ for OP). The relative concentrations of NPEOs and OPEOs reflect their consumption pattern and are consistent with ratio reported in literature [6] but are slightly different from

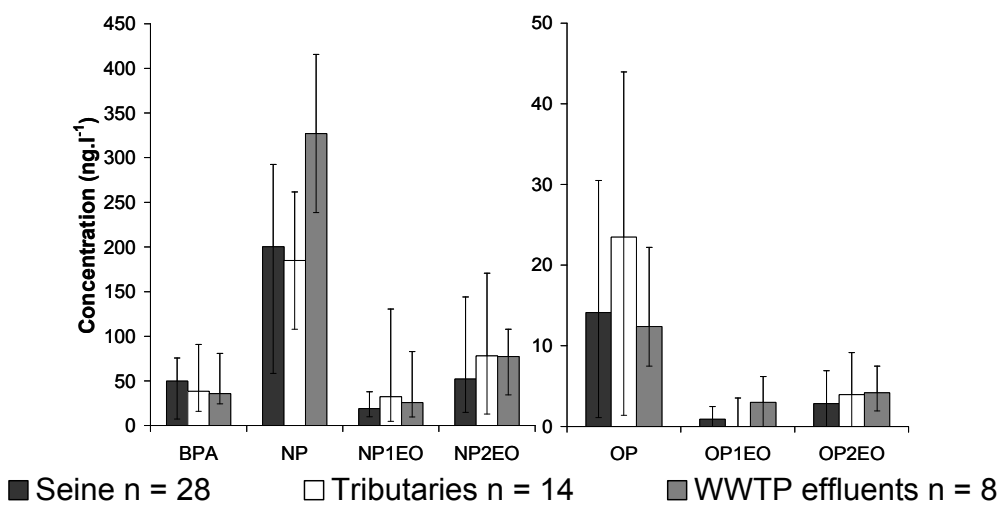

Figure 2: Total concentrations in surface water (Seine River and tributaries) and in WWTP effluents. 
Table 2: $\quad$ Concentrations $\left(\right.$ ng. $\left.1^{-1}\right)$ in surface water, this study vs. literature.

\begin{tabular}{ccccccccc}
\hline Location & $\mathrm{BPA}$ & $\mathrm{NP}$ & $\mathrm{NP}_{1} \mathrm{EO}$ & $\mathrm{NP}_{2} \mathrm{EO}$ & $\mathrm{OP}$ & $\mathrm{OP}_{1} \mathrm{EO}$ & $\mathrm{OP}_{2} \mathrm{EO}$ & Reference \\
\hline Glatt River & 9.4 & 64 & 18 & 9.4 & 2.4 & - & - & {$[15]$} \\
Masan Bay & - & 18.9 & 24.2 & 115.4 & - & - & - & {$[18]$} \\
$\begin{array}{c}\text { Seine River } \\
\text { downstream }\end{array}$ & - & 168 & 82 & 59 & - & - & - & {$[13]$} \\
Jamaica bay & - & 201 & 157 & 320 & 3.3 & 26 & 4.9 & {$[19]$} \\
Tiber River & 80 & 240 & 360 & 270 & - & - & - & {$[20]$} \\
Seine River & 50 & 200 & 19 & 52 & 14 & 1 & 3 & This study \\
upstream* & $7-127$ & $58-426$ & $10-79$ & $15-414$ & $1-81$ & $<1-4$ & $<1-14$ & \\
\hline
\end{tabular}

* Median, min - max values.

values given by Ying et al. [5], i.e. $80 \%$ for NPEOs and 20\% for OPEOs. As regard the Water Framework Directive, the total concentrations for NP (200 \pm 92 ng. $\left.1^{-1}\right)$ and OP $\left(14 \pm 16\right.$ ng..$\left.^{-1}\right)$ do not exceed the environmental quality standards (300 and $100 \mathrm{ng} . \mathrm{l}^{-1}$ for NP and OP, respectively). Concentrations found in this study on the upper part of the Seine basin are in good agreement with concentrations reported in the lower part by Cailleaud et al. [13]. Moreover, and in spite of the strong human pressures on the Seine basin, the BPA and APEO concentrations measured in the Seine River appear in the same order of magnitude than concentrations reported in literature (Table 2). Contrary to some studies emphasising higher levels of APEOs and BPA in WWTP effluents comparatively to surface water [14-16], comparable concentrations were found in WWTP effluents and in surface water, except for NP which is more concentrated in WWTP effluents. Comparatively to other studies, the WWTP effluent concentrations found in this study are similar to the results reported by Jonkers et al. [15] in Switzerland but far lower than those reported in China and Austria $[16,17]$. The low concentrations in WWTP effluents probably reflect the decrease of APEO consumption for both industrial and domestic applications due to the European Directive 2003/53/CE.

In spite of their hydrophobicity (log $\mathrm{K}_{\mathrm{ow}}$ ranging from 3.2 for BPA to 4.6 for NP, Ahel and Giger [21]), APEOs and BPA are weakly associated with suspended solids, except for OP. Indeed, particulate phase only represent $20 \%$ of total concentration of APEOs and 5\% of BPA for each surface water and WWTP effluents. Similar distributions between dissolved and particulate phase were found in the downstream part of the Seine basin by Cailleaud et al. [13]. The higher particulate proportion of OP (between 40 and $50 \%$ ) could probably be explained by the sorption of this compound on suspended solids. Indeed, Johnson et al. [22] demonstrated that up to $40 \%$ of OP can be sorbed onto suspended solids under low flow condition.

\subsubsection{Evolution of the pollutant concentrations along the Seine River}

The individual concentrations along the $300-\mathrm{km}$ transect of the Seine River $\left(\mathrm{S}_{1-10}\right)$ are illustrated in Figure 3. For stations downstream of $\mathrm{WWTP}_{1,2,4}$, no significant impact on the concentrations was noticed. This is mainly related to the low concentrations of WWTP effluents and low volumes discharged (1 - 4 
$\mathrm{m}^{3} \cdot \mathrm{s}^{-1}$ ) comparatively to the Seine River (about $150 \mathrm{~m}^{3} \cdot \mathrm{s}^{-1}$ ). To the opposite, a significant increase of concentrations is observed at $\mathrm{S}_{7}$ downstream of $\mathrm{WWTP}_{3}$ (from 324 at $\mathrm{S}_{6}$ to $751 \mathrm{ng} . \mathrm{l}^{-1}$ at $\mathrm{S}_{7}$ in April and from 304 to $526 \mathrm{ng} . \mathrm{l}^{-1}$ in July). This impact is related to higher volume discharged $\left(17 \mathrm{~m}^{3} . \mathrm{s}^{-1}\right.$ against $150 \mathrm{~m}^{3} . \mathrm{s}^{-1}$ for the Seine River) and to a lesser extent to the higher concentrations measured in the effluents. Actually, the $\mathrm{WWTP}_{3}$ is the biggest plant of the Parisian conurbation treating approximately $75 \%$ of the Parisian wastewater, i.e. 1.7 million $\mathrm{m}^{3}$ (6.0 millions of population-equivalents). This impact is clearly visible at $\mathrm{S}_{7}$ but becomes less perceptible at $\mathrm{S}_{8}$ due to the Seine River dilution by the Oise tributary $\left(\mathrm{T}_{4}\right.$, Figure 1$)$, accounting for $40 \%$ of total river flow.

\subsection{Alkylphenol ethoxylate and bisphenol A mass loads}

For both sampling campaigns, daily mass loads $\left(\mathrm{g} \cdot \mathrm{d}^{-1}\right)$ were calculated according to the total concentrations (ng. $\left.1^{-1}\right)$ and the river flows $\left(\mathrm{m}^{3} \cdot \mathrm{s}^{-1}\right)$. These values were obtained from different river monitoring stations.

\subsubsection{Temporal variation of the pollutant loads}

In order to assess the temporal variation of the pollutant loads, the loads $\left(\mathrm{g} . \mathrm{d}^{-1}\right)$ at $\mathrm{S}_{8}$ and $\mathrm{S}_{10}$ for all sampling campaigns available were examined (Figure 4 ). The distance between $\mathrm{S}_{8}$ and $\mathrm{S}_{10}$ is about $150 \mathrm{~km}$ and the hydraulic time is evaluated between 3 and 5 days.

As underlined by Figure 4, a limited temporal variation is observed for BPA between median- and low-water periods. While the BPA loads in April $\left(\mathrm{S}_{8}\right.$ and $\mathrm{S}_{10}$ ) or in May $\left(\mathrm{S}_{8}\right)$ ranged from 1,360 to $1,776 \mathrm{~g} . \mathrm{d}^{-1}$, those observed during lowwater period are comprised between 611 and 1,370 g.d ${ }^{-1}$. In contrast, the APEO loads significantly vary between spring and summer. While the APEO loads (sum of 6 congeners) in April reach 10,741 and 10,108 g.d $\mathrm{d}^{-1}$ at $\mathrm{S}_{8}$ and $\mathrm{S}_{10}$, far lower loads are indeed observed in July $\left(3,822\right.$ and 3,931 g. $\mathrm{d}^{-1}$, Figure 4). This temporal variability is mainly explained by the important decrease of Seine River

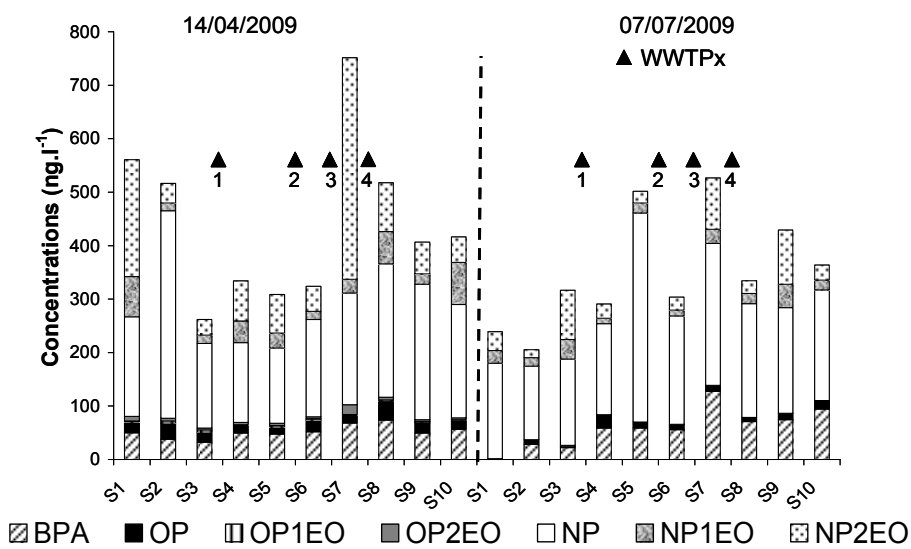

Figure 3: $\quad$ APEO and BPA concentrations in the Seine River. 


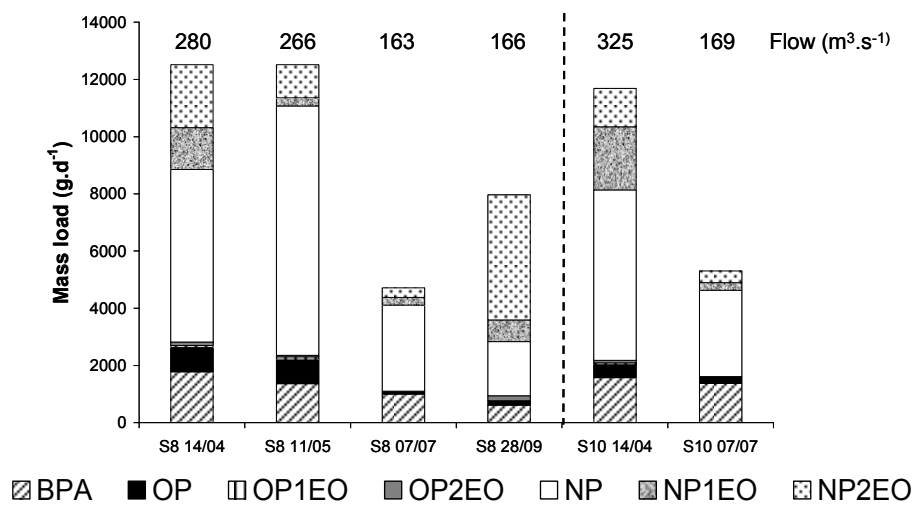

Figure 4: Temporal variation of the APEO and BPA loads.

flow between both dates $\left(280 v s .163 \mathrm{~m}^{3} \cdot \mathrm{s}^{-1}\right.$, i.e. $\left.58 \%\right)$ and to a lesser extent by the difference of concentrations at $\mathrm{S}_{8}$. Whether no clear seasonal variation of APEO concentrations was highlighted in our study, the lower concentration at $\mathrm{S}_{8}$ was however noted in July (263 ng..$\left.^{-1}\right)$ comparatively to April (444 ng. $\left.\mathrm{l}^{-1}\right)$.

Figure 4 also underlines an evolution of the $\mathrm{NP}_{1-2} \mathrm{EO}$ and $\mathrm{OP}_{1-2} \mathrm{EO}$ distributions between $\mathrm{S}_{8}$ and $\mathrm{S}_{10}$. This change probably results from in-situ processes, more likely through biodegradation. It is actually known that the biodegradation leading to the formation of APEOs with shorter ethoxylate chain affect the distributions of the different congeners (John and White [9]). As attested by the change of $\mathrm{NP}_{1-2} \mathrm{EO}$ and $\mathrm{OP}_{1-2} \mathrm{EO}$ proportions between both stations, biodegradation seems to be more important in April than in July.

\subsubsection{Evolution of pollutant loads along the Seine River}

Figure 5 illustrates the evolution of the pollutant loads along the Seine River (from $\mathrm{S}_{1}$ to $\mathrm{S}_{10}$ ) for both sampling campaigns. Whatever the campaign considered, results show an increase of the pollutant loads from up- $\left(S_{1}\right)$ to down-stream $\left(\mathrm{S}_{10}\right)$ stations. Typically, the BPA loads in April rise from $154 \mathrm{~g} . \mathrm{d}^{-1}$ at $S_{1}$ to 1,576 at $S_{10}$ while the APEO loads increase from 1,580 to 10,108 g.d $\mathrm{d}^{-1}$ in the same time (Figure 5).

At the Seine basin outlet $\left(\mathrm{S}_{10}\right)$, the exported loads in April and July to the lower part of the Seine basin were respectively evaluated at 1,576 and 1,373 g.d $\mathrm{d}^{-1}$ for BPA and at 10,108 and 3,931 g.d $\mathrm{d}^{-1}$ for APEOs. The WWTP $1,2,4$ seem to have a moderate impact on the pollutant loads conveyed by the Seine River. As previously mentioned, this can be mainly related to their low effluent discharges comparatively to the Seine River and their low concentrations.

To the opposite, the $\mathrm{WWTP}_{3}$ has a significant impact on the Seine River pollutant loads. Due to the $\mathrm{WWTP}_{3}$ discharge, the APEO and BPA loads between $S_{6}$ and $S_{7}$ increase from 5,173 to 11,681 g.d $\mathrm{d}^{-1}$ in April and from 2,576 to 5,240 g. $\mathrm{d}^{-1}$ in July. As previously explained, this impact is related to the high flow of the WWTP 3 effluents $\left(17 \mathrm{~m}^{3} \cdot \mathrm{s}^{-1}\right)$ representing up to $15 \%$ of Seine River flow $\left(\mathrm{S}_{7}\right)$. Contrary to the results found for concentrations, the $\mathrm{WWTP}_{3}$ impact 


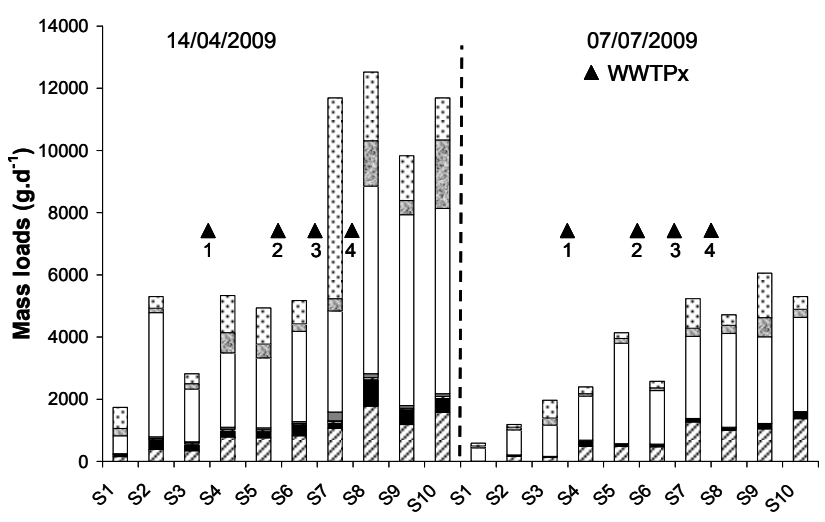

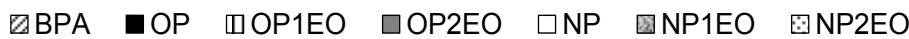

Figure 5: Evolution of pollutant loads along the Seine River.

on the pollutant loads is still visible on the downstream stations. A comparison between the WWTP loads (sum of 4 WWTPs) and the total inputs to the Seine River system ( $\mathrm{S}_{1}$, tributaries and WWTPs) attests to the higher contribution of the WWTPs in July comparatively to April. For instance, the contribution of WWTP effluents to total inputs rises from $13 \%$ to $36 \%$ for BPA and from $10 \%$ to $40 \%$ for APEOs. These results are mainly related to the decrease of tributaries and $\mathrm{S}_{1}$ flows between spring and summer whereas the WWTP discharge flows are constant.

\subsubsection{Inputs and exported pollutant loads at the scale of the Seine basin}

To assess the dynamic of the pollutants within the Seine River, mass balances between the inputs ( $\mathrm{S}_{1}$, tributaries and WWTPs) and the pollutant loads measured at the basin outlet $\left(\mathrm{S}_{10}\right)$ were carried out. Thus, the ratio between the inputs and the exported loads were calculated for both campaigns (Table 3).

The comparison between the inputs and the exported loads highlights two different cases. For BPA, the inputs for both campaigns appear lower than the exported loads (ratio inputs vs. exported loads respectively equal to 0.7 and 0.5 ). Considering that a production of BPA cannot occur within the Seine River [4], these ratios indicate that not all sources were account for. To asses more accurate mass balances, the other WWTPs present in the Seine basin (about 250 plants with capacity below 2,000 population-equivalents) have to be considered along the Seine transect.

To the opposite, APEOs exhibit ratios above 1 suggesting that the inputs are higher than the exported loads (Table 3). These values point out the in-stream removal of APEOs along the Seine River, probably through in-situ processes such as adsorption on particles and sedimentation [22] and/or biodegradation [9, 10]. Out of these different processes, the biodegradation is likely the predominant one [5]. Results found in April and to a lesser extent in July reveal that the removal of APEOs and the number of ethoxylate units are correlated the longer ethoxylate chain, the higher the removal $\left(3.5\right.$ for $\mathrm{NP}_{2} \mathrm{EO}>1.7$ for 
Table 3: $\quad$ Inputs and exported loads $\left(\mathrm{g} \cdot \mathrm{d}^{-1}\right)$ in the Seine River.

\begin{tabular}{|c|c|c|c|c|c|c|}
\hline \multirow{2}{*}{ compound } & \multicolumn{2}{|c|}{ April } & \multicolumn{2}{|c|}{ July } & \multicolumn{2}{|c|}{ Inputs / exported } \\
\hline & Inputs & exported & Inputs & exported & $14 / 04 / 09$ & 07/07/09 \\
\hline BPA & 1,164 & 1,576 & 728 & 1,373 & 0.7 & 0.5 \\
\hline $\mathrm{OP}$ & 544 & 447 & 135 & 235 & 1.2 & 0.6 \\
\hline $\mathrm{OP}_{1} \mathrm{EO}$ & 132 & 68 & 10 & $\mathrm{NC}$ & 2.0 & - \\
\hline $\mathrm{OP}_{2} \mathrm{EO}$ & 282 & 87 & 20 & $\mathrm{NC}$ & 3.2 & - \\
\hline NP & 6,138 & 5,959 & 3,466 & 3,019 & 1.0 & 1.1 \\
\hline $\mathrm{NP}_{1} \mathrm{EO}$ & 3,282 & 2,205 & 467 & 268 & 1.7 & 1.7 \\
\hline $\mathrm{NP}_{2} \mathrm{EO}$ & 5,175 & 1,342 & 676 & 409 & 3.5 & 1.7 \\
\hline
\end{tabular}

$\mathrm{NP}_{1} \mathrm{EO}>1.0$ for NP in April, Table 3). Considering the views of transformation reactions of nonylphenol ethoxylates provided by Giger et al. [23], results implied that the transformation of $\mathrm{NP}_{2} \mathrm{EO}$ into $\mathrm{NP}_{1} \mathrm{EO}$ or nonylphenolethoxyacetic acid $\left(\mathrm{NP}_{2} \mathrm{EC}\right)$ is faster than its formation from NPnEO. Similarly, our results suggest that the transformation of $\mathrm{NP}_{1} \mathrm{EO}$ into $\mathrm{NP}$ or nonylphenolacetic acid $\left(\mathrm{NP}_{1} \mathrm{EC}\right)$ is faster than its formation from longer homolog.

\section{Conclusion}

This study provides first relevant information on the occurrence and fate of APEOs and BPA at the scale of the upper part of the Seine basin. BPA concentrations range from 7.2 to 127 ng. $1^{-1}$ in surface water. For APEOs, higher concentrations for surface water $\left(324 \pm 153\right.$ ng. $\left.1^{-1}\right)$ were observed. Based on our first results, no spatial variability of concentrations between up- and downstream sites as well as any seasonal variability were highlighted. To the opposite, an increase of the pollutant loads between up- and down-stream sites was noticed. Contrary to the limited seasonal variation of BPA, the APEO loads significantly vary $\left(10,108\right.$ and 3,931 g.d $\left.\mathrm{d}^{-1}\right)$. At present, this seasonal variation has to be better examined in relation to the hydrological dynamic conditions. Therefore, further investigations will be soon carried out.

The assessment of the pollutant mass balances between the inputs and the exported loads reveal that the BPA inputs are lower than the exported loads suggesting that not all sources were considered. For APEOs, the inputs appear higher than the exported loads, underscoring their in-stream removal during their transport within the Seine River. Results reveal that this removal and the number of ethoxylate units are correlated - the longer ethoxylate chain, the higher the removal. Whether our result do not allow the identification of the transformation reactions involved in the aquatic system, our sampling approach nevertheless enables a better understanding of the APEO behaviour. In the future, the analyses of $\mathrm{NP}_{1-2} \mathrm{EC}$ intermediates will improve this understanding.

\section{Acknowledgement}

The authors would thank the Interdepartmental Association for Sewage Disposal in the Paris Conurbation (SIAAP) for their technical help. 


\section{References}

[1] Brian, J.V., Harris, C.A., Scholze, M., Kortenkamp, A., Booy, P., Lamoree, M., Pojana, G., Jonkers, N., Marcomini, A., \& Sumpter, J.P., Evidence of estrogenic mixture effects on the reproductive performance of fish. Environmental Science \& Technology, 41(1), pp. 337-344, 2007.

[2] Wetherill, Y.B., Akingbemi, B.T., Kanno, J., McLachlan, J.A., Nadal, A., Sonnenschein, C., Watson, C.S., Zoeller, R.T., \& Belcher, S.M., In vitro molecular mechanisms of bisphenol A action. Reproductive Toxicology, 24(2), pp. 178-198, 2007.

[3] Soares, A., Guieysse, B., Jefferson, B., Cartmell, E., \& Lester, J.N., Nonylphenol in the environment: A critical review on occurrence, fate, toxicity and treatment in wastewaters. Environment International, 34(7), pp. 1033-1049, 2008.

[4] Vandenberg, L.N., Hauser, R., Marcus, M., Olea, N., \& Welshons, W.V., Human exposure to bisphenol A (BPA). Reproductive Toxicology, 24(2), pp. 139-177, 2007.

[5] Ying, G.-G., Williams, B., \& Kookana, R., Environmental fate of alkylphenols and alkylphenol ethoxylates--a review. Environment International, 28(3), pp. 215-226, 2002.

[6] Sharma, V.K., Anquandah, G.A.K., Yngard, R.A., Kim, H., Fekete, J., Bouzek, K., Ray, A.K., \& Golovko, D., Nonylphenol, octylphenol, and bisphenol-A in the aquatic environment: A review on occurrence, fate, and treatment. Journal of Environmental Science and Health Part aToxic/Hazardous Substances \& Environmental Engineering, 44(5), pp. 423-442, 2009.

[7] Bhattacharya, H., Xiao, Q., \& Lun, L., Toxicity studies of nonylphenol on rosy barb (Puntius conchonious): A biochemical and histopathological evaluation. Tissue and Cell, 40(4), pp. 243-249, 2008.

[8] Uguz, C., Iscan, M., Ergüven, A., Isgor, B., \& Togan, I., The bioaccumulation of nonyphenol and its adverse effect on the liver of rainbow trout (Onchorynchus mykiss). Environmental Research, 92(3), pp. 262-270, 2003.

[9] John, D.M. \& White, G.F., Mechanism for Biotransformation of Nonylphenol polyethoxylates to xenoestrogens in Pseudomonas putida. Journal of Bacteriology, 180(17), pp. 4332-4338, 1998.

[10] Jonkers, N., Knepper, T.P., \& De Voogt, P., Aerobic biodegradation studies of nonylphenol ethoxylates in river water using liquid chromatographyelectrospray tandem mass spectrometry. Environmental Science \& Technology, 35(2), pp. 335-340, 2001.

[11] Zhang, L., Gibble, R., \& Baer, K.N., The effects of 4-nonylphenol and ethanol on acute toxicity, embryo development, and reproduction in Daphnia magna. Ecotoxicology and Environmental Safety, 55(3), pp. 330337, 2003.

[12] Meybeck, M., Lestel, L., Bonte, P., Moilleron, R., Colin, J.L., Rousselot, O., Herve, D., de Ponteves, C., Grosbois, C., \& Thevenot, D.R., Historical 
perspective of heavy metals contamination $(\mathrm{Cd}, \mathrm{Cr}, \mathrm{Cu}, \mathrm{Hg}, \mathrm{Pb}, \mathrm{Zn})$ in the Seine River basin (France) following a DPSIR approach (1950-2005). Science of the Total Environment, 375(1-3), pp. 204-231, 2007.

[13] Cailleaud, K., Forget-Leray, J., Souissi, S., Lardy, S., Augagneur, S., \& Budzinski, H., Seasonal variation of hydrophobic organic contaminant concentrations in the water-column of the Seine Estuary and their transfer to a planktonic species Eurytemora affinis (Calanoïd, copepod). Part 2: Alkylphenol-polyethoxylates. Chemosphere, 70(2), pp. 281-287, 2007.

[14] González, S., Petrovic, M., \& Barceló, D., Simultaneous extraction and fate of linear alkylbenzene sulfonates, coconut diethanol amides, nonylphenol ethoxylates and their degradation products in wastewater treatment plants, receiving coastal waters and sediments in the Catalonian area (NE Spain). Journal of Chromatography A, 1052(1-2), pp. 111-120, 2004.

[15] Jonkers, N., Kohler, H.P.E., Dammshauser, A., \& Giger, W., Mass flows of endocrine disruptors in the Glatt River during varying weather conditions. Environmental Pollution, 157(3), pp. 714-723, 2009.

[16] Yu, Y., Zhai, H., Hou, S., \& Sun, H., Nonylphenol ethoxylates and their metabolites in sewage treatment plants and rivers of Tianjin, China. Chemosphere, 77(1), pp. 1-7, 2009.

[17] Clara, M., Scharf, S., Scheffknecht, C., \& Gans, O., Occurrence of selected surfactants in untreated and treated sewage. Water Research, 41(19), pp. 4339-4348, 2007.

[18] Li, D., Dong, M., Shim, W.J., Yim, U.H., Hong, S.H., \& Kannan, N., Distribution characteristics of nonylphenolic chemicals in Masan Bay environments, Korea. Chemosphere, 71(6), pp. 1162-1172, 2008.

[19] Ferguson, P.L., Iden, C.R., \& Brownawell, B.J., Analysis of alkylphenol ethoxylate metabolites in the aquatic environment using liquid chromatography-electrospray mass spectrometry. Analytical Chemistry, 72(18), pp. 4322-4330, 2000.

[20] Patrolecco, L., Capri, S., De Angelis, S., Pagnotta, R., Polesello, S., \& Valsecchi, S., Partition of nonylphenol and related compounds among different aquatic compartments in Tiber River (Central Italy). Water Air and Soil Pollution, 172(1-4), pp. 151-166, 2006.

[21] Ahel, M. \& Giger, W., Aqueous solubility of alkylphenols and alkylphenol polyethoxylates. Chemosphere, 26(8), pp. 1461-1470, 1993.

[22] Johnson, A.C., White, C., Besien, T.J., \& Jürgens, M.D., The sorption potential of octylphenol, a xenobiotic oestrogen, to suspended and bedsediments collected from industrial and rural reaches of three English rivers. Science of the Total Environment, 210-211, pp. 271-282, 1998.

[23] Giger, W., Gabriel, F.d.r.L.P., Jonkers, N., Wettstein, F.E., \& Kohler, H.P.E., Environmental fate of phenolic endocrine disruptors: field and laboratory studies. Philosophical Transactions of the Royal Society A: Mathematical, Physical and Engineering Sciences, 367(1904), pp. 39413963, 2009. 